\title{
A Critical Review of Symptom Management of Auditory Hallucinations in Patient with Schizophrenia
}

\author{
Suryani \\ Fakultas Keperawatan, Universitas Padjadjaran \\ Email: ynsuryani@yahoo.com
}

\begin{abstract}
Auditory hallucinations are a key symptom of schizophrenia. It is estimated that the prevalence of auditory hallucinations in people with schizophrenia range from $64.3 \%$ to $83.4 \%$. The auditory hallucinations impacted on daily lives of the sufferer. An extensive review of the literature was undertaken to find symptom management that has been developed in reducing auditory hallucinations from CINAHL, PsyInfo, Health and Medical Complete, ProQuest Psychology Journals, ProQuest Social Journals, Science Direct, Web of Science and Scopus. Based on the analysis of the 15 articles, evidence was suggested that CBT and other psychological treatments have beneficial for individuals who experience auditory hallucinations. However, individuals who experience auditory hallucinations are not just sufferers who need to be treated but people who can develop their own strategies of living with auditory hallucinations. Therefore it is important for nurses to involve them in the management of the auditory hallucinations.
\end{abstract}

Key words: Auditory hallucinations, literature review, symptom management.

\section{Reviu Kritis terhadap Pengelolaan Gejala Halusinasi Pendengaran pada Pasien Skizofrenia}

\begin{abstract}
Abstrak
Halusinasi pendengaran merupakan gejala utama skizofrenia. Prevalensi halusinasi pendengaran pada penderita skizofrenia diperkirakan berkisar antara 64,3\% sampai 83,4\%. Halusinasi pendengaran berdampak pada kehidupan sehari-hari penderitanya. Kajian literatur ini dilakukan untuk menemukan manajemen gejala yang telah dikembangkan dalam mengurangi halusinasi pendengaran dari CINAHL, PsycINFO, Kesehatan dan Kedokteran Lengkap, Jurnal Psikologi Proquest, Jurnal Sosial Proquest, Science Direct, Web of Science dan Scopus. Berdasarkan analisis terhadap dari 15 artikel, ada bukti yang menunjukkan bahwa CBT dan perawatan psikologis lainnya bermanfaat bagi individu yang mengalami halusinasi pendengaran dalam mengatasinya. Namun, individu yang mengalami halusinasi pendengaran bukan hanya penderita yang perlu diobati tetapi individu yang dapat mengembangkan strategi mereka sendiri hidup dengan halusinasi pendengaran. Karena itu penting bagi perawat untuk melibatkan mereka dalam manajemen halusinasi tersebut.
\end{abstract}

Kata kunci: Halusinasi pendengaran, kajian literature, manajemen gejala. 
Suryani: A Critical Review of Symptom Management of Auditory Hallucinations

\section{Background}

According to the DSM V, "The characteristic symptoms of schizophrenia involve a range of cognitive, behavioral, and emotional dysfunctions, but no single symptom is pathognomonic of the disorder... At least one of these symptoms must be the clear presence of delusions (Criterion $\mathrm{Al}$ ), hallucinations (Criterion A2), or disorganized speech (Criterion A3)" (APA, 2013, p. 97). The most common symptom of schizophrenia is hallucinations (Uhlhass and Mishara, 2006). The most common form of hallucinations in schizophrenia is auditory hallucinations (Waters, 2010; Suryani, 2013).

According to the DSM V, auditory hallucinations are "perception-like experiences that occur without an external stimulus" (APA, 2013, p. 87). The voices $(\mathrm{AH})$ can range from a single word to a short phrase, to voices conversing with each other. They can also manifest as a sound such as music, bangs, claps, or sounds from the environment (Badcock, 2008).

A study by Singh, Sharan, Kulhara (2002) in Hong Kong of 75 people diagnosed with schizophrenia suggested that auditory hallucinations have a significant impact on individuals with chronic schizophrenia. They found that $95 \%$ of participants had financial difficulties, $87 \%$ developed problems with sexual performance and $81 \%$ experienced disruptive relationships with their family. Similarly, a study by England (2005) in North America of 387 people diagnosed with schizophrenia who experienced auditory hallucinations suggested that there was a correlation between participants' perceptions of hearing voices and their self-esteem and quality of life. The findings indicated that participants who have a negative experience of auditory hallucinations had low selfesteem and a reduced quality of life.

A recent study by Lysaker and La Rocco (2009) set in Indiana, USA, explored healthrelated quality of life of 102 adults with a schizophrenia spectrum disorder. They found that people diagnosed with schizophrenia who experience auditory hallucinations have poor social and emotional functioning (Lysaker \& LaRocco, 2009) resulting in loss of employment and difficulty in forming social relationships (Cangas, Garcio-Mostes, Lopez de Lemus \& Olivencia, 2003).

The often un-abating presence of auditory hallucinations has led individuals to seek strategies to reduce the symptom. Currently, treatment programs are not only focused on antipsychotic medication but have moved to a more comprehensive therapy (Adame \& Knudson, 2007).

\section{Methods}

In undertaking a review of literature, an extensive computerized search was conducted using all identified keywords and index terms used by respective databases. The following literature databases were searched using these key words: symptom management, auditory hallucinations', Schizophrenia' and hearing voices. Database searched were: the CINAHL and PsycInfo between 2000 to present, as both search engines are considered to be the most comprehensive and relevant databases for the review of literature (Shultz, Dell \& Bodan, 2009). In addition, searching was also done using search engine such as Health and Medical Complete, Proquest Psychology Journals, Proquest Social Journals, Science Direct, Web of Science and Scopus. Publications were limited to English language only. Searches were performed of the references of the key papers included in the review.

The searching of related literature was conducted using Boolean search terms included "and" which retrieves only article with both words (example exclusive symptom management and auditory hallucinations), and "or" which would locate all articles with either words. Author searching was also conducted by searching the name of authors of relevant reports in each databse.

In searching the article, the authors set out the inclusion and exclusion criteria in the protocol to ensure that the boundaries of the review question are clearly defined (CRD, 2009). The inclusion and exclusion criteria determine the focus, nature, and limits of the review. An article were eligible for inclusion if they met the following criteria : 
Suryani: A Critical Review of Symptom Management of Auditory Hallucinations

Table 1 Inclusion and Exclusion Criteria for Selecting Article

\begin{tabular}{ll}
\hline \multicolumn{1}{c}{ Inclusion Criteria } & \multicolumn{1}{c}{ Exclusion Criteria } \\
\hline English language papers & Non - English language papers \\
Primary research papers & Review of primary research papers, \\
Availability of full text articles & Abstract only \\
Papers published between the years 2000 to present & Papers published before the years 2000 \\
\hline
\end{tabular}

\section{Result}

This search located 16 articles from CINAHL and 85 articles from Psycinfo. After reading all article abstracts, few studies were located that directly related to the focus of this study.

Table 2 The Articles that Include in this Study

\begin{tabular}{|c|c|c|}
\hline The title of the study & Authors & Label \\
\hline $\begin{array}{l}\text { Challenging the omnipotence of voices: group } \\
\text { cognitive behavior therapy for voices. }\end{array}$ & $\begin{array}{l}\text { Chadwick, P., Sambrooke, S., Raschc, S } \\
\text { \& Davies, E. (2000). }\end{array}$ & $\mathrm{S} 1$ \\
\hline $\begin{array}{l}\text { Group treatment of auditory hallucination: Exploratory } \\
\text { study of effectiveness. }\end{array}$ & $\begin{array}{l}\text { Wykes, T. Hayward, P. \& Landau, S. } \\
(2000)\end{array}$ & $\mathrm{S} 2$ \\
\hline $\begin{array}{l}\text { Cognitive behaviour therapy with coping training for } \\
\text { persistent auditory hallucinations in schizophrenia: a } \\
\text { naturalistic follow-up study of the durability of effects. }\end{array}$ & $\begin{array}{l}\text { Wiersma, D., Jenner, J.A., van de Willige, } \\
\text { G., Spakman, M. \& Nienhuis, F.J. (2001). }\end{array}$ & $\mathrm{S} 3$ \\
\hline $\begin{array}{l}\text { The efficacy of using a personal stereo to treat auditory } \\
\text { hallucinations: Preliminary findings. } \\
\text { Behaviour Modification }\end{array}$ & $\begin{array}{l}\text { Jonston, O. Gallaghar, A.G., McMahon, P. } \\
\text { \& King, D.J. (2002) }\end{array}$ & $\mathrm{S} 4$ \\
\hline $\begin{array}{l}\text { Long-term effect of teaching behaviour strategies for } \\
\text { managing persistent auditory hallucinations }\end{array}$ & $\begin{array}{l}\text { Buccheri, R., Trygstad, L., Kaas, M.J., } \\
\text { Hopkin, R., Dowling, G., White, K., } \\
\text { Griffin, Hebert, P. (2004). }\end{array}$ & S5 \\
\hline $\begin{array}{l}\text { Self-care symptom management strategies for auditory } \\
\text { hallucinations among patients with schizophrenia in } \\
\text { Taiwan. }\end{array}$ & Tsai, Y. \& Chen, C. (2005). & S6 \\
\hline $\begin{array}{l}\text { "Hitting" voices of schizophrenia patients may } \\
\text { lastingly reduce persistent auditory hallucinations } \\
\text { and their Burden: } 18 \text { month outcome of randomized } \\
\text { controlled trial. }\end{array}$ & $\begin{array}{l}\text { Jenner, J.A., Nienhuis, F.J., Willige, G. \& } \\
\text { Wiersma, D. (2006) }\end{array}$ & S7 \\
\hline $\begin{array}{l}\text { Behavioural management of command hallucinations } \\
\text { to harm in schizophrenia }\end{array}$ & $\begin{array}{l}\text { Buccheri, R., Trygstad, L., \& Dowling, G. } \\
\text { A. (2007) }\end{array}$ & S8 \\
\hline $\begin{array}{l}\text { Efficacy of cognitive nursing intervention for voice } \\
\text { hearing. Perspective Psychiatric Care, } 43(2), 69-76\end{array}$ & England (2007) & S9 \\
\hline $\begin{array}{l}\text { Auditory hallucination coping techniques and their } \\
\text { relationship to psychotic symptomatology }\end{array}$ & $\begin{array}{l}\text { Hayashi, N., Igarashi, Y., Suda, K., \& } \\
\text { Nakagawa, S. (2007) }\end{array}$ & S10 \\
\hline $\begin{array}{l}\text { Effects of a symptom management program on auditory } \\
\text { hallucinations in Thai outpatients with a diagnosis of } \\
\text { schizophrenia: A pilot study. }\end{array}$ & $\begin{array}{l}\text { Kanungpairn, T, Sitthimongko, Y, } \\
\text { Wattanapailin, A and Klainin, P (2007). }\end{array}$ & S11 \\
\hline $\begin{array}{l}\text { Acceptance and Commitment Therapy applied to } \\
\text { treatment of auditory hallucinations. }\end{array}$ & $\begin{array}{l}\text { Veiga-Martínez, C. \& Pérez-Álvarez, M. } \\
\text { \& Garcia-Montes, J. (2008). }\end{array}$ & S12 \\
\hline $\begin{array}{l}\text { A randomized controlled trial of group cognitive- } \\
\text { behavioral therapy vs. enhanced supportive therapy for } \\
\text { auditory hallucinations, }\end{array}$ & $\begin{array}{l}\text { Penn, D. L, Meyer, P. S., Evans, E., Wirth, } \\
\text { R. J., Cai, K., \& Burchinal, M. (2009) }\end{array}$ & S13 \\
\hline $\begin{array}{l}\text { Salat and Dhikr to Dispel Voices: The Experience of } \\
\text { Indonesian Muslim with Chronic Mental Illness }\end{array}$ & Suryani (2013) & S14 \\
\hline $\begin{array}{l}\text { The effects of auditory hallucination symptom } \\
\text { management programme for people with schizophrenia: } \\
\text { a quasi-experimental design. }\end{array}$ & Yang, Lee, Lo, and Beckstead (2015). & $\mathrm{S} 15$ \\
\hline
\end{tabular}


Suryani: A Critical Review of Symptom Management of Auditory Hallucinations

The vast majority of articles were concerned with neuroleptic medications used to treat auditory hallucinations. A further search was conducted to include additional search engines: Health and Medical Complete, Proquest Psychology Journals, Proquest Social Journals, Science Direct, Web of Science and Scopus. The search finally yielded 87 articles. After considering the inclusion and exclusion criteria and the relevancy of the published article with the purpose of this study, 15 articles were include in this study.

The studies used descriptive (2 study), single case study (2 studies), quassy experiemnt (1 study), randomized controll trial (6 studies), prepost design (3 studies) and studies), Netherland (2 studies), Taiwan (2 studies), Australia (1 study), Japan (1 study), Thailand (1 study) and Indonesia (1 study). Four studies (S4, S10, S11 and S14) seek to understand self management while other 11 studies examine group therapy. All 11 studies specified the sample size and characteristic of the participants (Table 2).

\section{Discussion}

The literature indicates that self-management is an effective strategy for reducing auditory hallucinations (Buccheri, et al, 2004; Buccheri, Trygstad, and Dowling, 2007; Trygstad et al., 2002; Johnston, Gallaghar, McMahon \& King, 2002; and Tsai \& Chen, 2005). A single case study of the effectiveness of radio headphones in reducing the presence of auditory hallucinations was carried out by Johnston et al. (2002) in the UK. The participant, a 50-year-old woman, who had been experiencing auditory hallucinations for 12 years, was treated using a personal stereo over a three week period. The three weeks involved one week with no treatment, one week with treatment (personal stereo) and one week with control treatment. The findings of the study indicating that the use of a personal stereo could reduce the severity of auditory hallucinations. However, the use of such devices or being exposed to sounds had no effect on individuals' self-esteem and belief about the voices.

An exploratory descriptive study by
Tsai and Chen, (2005) concerning selfcare symptom management in people who experienced auditory hallucinations was carried out in Taiwan. The exploratory descriptive study involved 200 participants who were asked to describe their strategies in managing auditory hallucinations. Tsai and Chen (2005) found that most of the patients developed their own distraction techniques such as ignoring the voices, engaging in activities, and accepting or arguing with the voices. As this was a self-report study of Taiwanese people, the findings of this study are only representative for this group of people.

A Japanese study (Hayashi et al., 2007) of 144 people found that talking to someone and participating in hobbies such as playing games were the most effective coping strategies in managing auditory hallucinations, while retorting and reading aloud had minimal effect. Listening to appropriate and relaxing music was identified as being more effective than watching TV. The limitation of this study was the findings were just from a cross-sectional investigation into experience. Therefore, they should be tested in actual treatment settings.

A qualitative study by Suryani in Indonesia with 24 participants found different findings to those Hayashi's study. The findings of Suryani's study revealed that Salat dan Dhikr were used by participants to manage their auditory hallucinations. This spiritual approach was used by participants because they believe that the voices that they heard were related to evil and Satan. The participants confirmed that the very act of engaging in doing Salat and Dhikr was a potent means of stopping the voices. The findings need to be tested in a quantitative method such as quasi experimental study.

Besides self-management, group therapy was identified as effective in managing the presence of auditory hallucinations. Wykes, Hayward, and Landau (2000) in the UK conducted a study with sample size -21 participants. The format of the study involved participants undertaking six sessions of CBT with a particular focus on developing coping strategies to control the auditory hallucinations. Findings of the study suggested that CBT was effective in reducing 
Suryani: A Critical Review of Symptom Management of Auditory Hallucinations

distress and increasing coping strategies of the participants.

In 2005, Wykes, Parr, and Landau continued their study that was done in 1994 by conducting a randomised control trial using a larger sample (45 patients as the treatment group and 40 patients for the control group). The study found that from all measurements of the outcomes (social functioning, the characteristics of auditory hallucinations and self-esteem), only the social functioning of the participants had improved significantly following CBT. Wykes, Parr, and Landau (2005) speculated that the improvement of social functioning may have been the result of participants' involvement in group social activities and not as a result of Cognitive Therapy. In evaluating the findings of the study however, a number of factors need to be considered. First, during the course of the study a number of participants $(20 \%)$ had alterations to their medication which was an initial exclusion criterium for participation in the study. Second, $25 \%$ of the subjects in the control group received additional individual therapy to that of the experimental group, which may have influenced the treatment outcomes. Third, some participants $(17.6 \%)$ removed themselves from the study for individual reasons. In addition, there was no consistency in the level of skill competency between the group facilitators in conducting CBT. One of the recommendations of the authors was that CBT should be conducted by an expert trainer to achieve better outcomes (Wykes et al., 2005), and should consider random factors in analyzing the effect of the therapy because of the influence of the group in the analysis process.

Chadwick, Sambrooke, Raschc and Davies (2000) examined the effects of CBT on individuals' beliefs in the power of auditory hallucinations to control them. Twenty two participants took part in eight, one hour sessions of CBT facilitated by two trained facilitators. During the process of the CBT sessions, participants were required to discuss their experiences related to the omnipotence of voices and the control they had over them. Five weeks after completing the CBT program, the authors examined the effectiveness of the CBT program and found that the participants' control over the voices significantly increased, although there was no change in their affective symptom presentation. The decision to use an informal rather than a formal mode of evaluation to reduce the possibility of further stress to participants is commendable but it may limit the generalisability and application of the findings.

A year later, Wiersma, Jenner, van de Willige, Spakman and Nienhuis (2001) conducted a similar study using a large sample to examine the effects of CBT on the participants' social function and their psychotic symptoms. Forty participants with schizophrenia were assigned to treatment programs (CBT with coping training) as well as the usual treatment (medication, psychoeducation and family support). The findings of the study indicated that $18 \%$ of the participants experienced complete recovery (no more voices) and $60 \%$ of the participants experienced an improvement in their daily lives and social functioning. However, because of the lack of control measures on other treatments received by the participants and no record of the baseline conditions of the participants, the findings are inconclusive. An experimental study by Buccheri et al. (2004) in the USA examined the effectiveness of behavioural symptom management using a variety of techniques such as keeping busy, avoiding drugs, talking with someone, watching TV, saying 'stop' and 'go away', listening to relaxation tapes, using relaxation exercises, taking prescribed medication, and using ear plugs. Sixty-two people diagnosed with schizophrenia who experienced persistent auditory hallucinations were involved in ten sessions of group therapy in which the participants practiced a range of techniques previously mentioned. The findings indicated that there was a significant reduction of frequency of auditory hallucinations. The techniques which were most effective in reducing the frequency and distractibility of the auditory hallucinations were talking with someone and using ear plugs. The participants also reported that by joining the group their control over stress increased. The small number of participants and lack of a control group were the major limitations of this study. The author suggested that further research is needed to determine 
Suryani: A Critical Review of Symptom Management of Auditory Hallucinations

specific demographic characteristics and behavioural strategies with a large sample and an appropriate control group.

In a later paper, Buccheri et al. (2007) reported on a follow-up of their previous study. They found that after one year of therapy all participants (62 participants) in their experimental study continued to use a combination of strategies to reduce the impact of auditory hallucinations. In general, all of the characteristics of auditory hallucinations such as frequency, distress, loudness, etc. were reduced significantly.

A similar study to that of Buccheri et al. (2007) was conducted by England (2007) in Canada who examined the effectiveness of a modification of CBT called Cognitive Nursing Intervention (CNI) which was used to alleviate psychiatric symptoms, severity of auditory hallucinations and level of self-esteem. The randomised control trial involved 65 participants 44 of whom received their usual treatment (UT) plus CNI while 21 of the participants were assigned to the control (only received UT) group. The findings of the study indicated that there was a significant improvement in psychiatric symptom reduction and enhanced self-esteem of the participants who received UT plus CNI compared to those who only received UT. The small number of participants and ambiguity of the influence of UT on the participants are two limitations. The authors suggest that further research is required into the effectiveness of the CBT or CNI.

Another similar study to that Buccheri et al. (2007) was conducted by Kanungpairn, Sitthimongkol, Wattanapailin, and Klainin, (2007) in Tailand. The study used symptom management that was developed by Bucchery et all to test in Thailand's patient with schizophrenia. Eighteen Thai outpatients diagnosed with schizophrenia were divided into a control group and an experimental group. Those who were in the experimental group received a 10 -session symptom management program, while the control group received the usual care. The participants were assessed at baseline and post-treatment. The results revealed that the participants who attended the symptom management program experienced significantly decreased overall scores of the characteristics and severity of auditory hallucinations. However, because of the small number of the participants ( 9 experiment and 9 control), the findings could not be generalized. Need further study with more samples.

Jenner, Nienhuis, Willige, and Wiersma (2006) in the Netherlands conducted a study using a randomised control trial design to explore behavioral management of hallucinations in relation to harm in people with schizophrenia. Jenner et al. (2006) developed an approach called Hallucinationfocused Integrative Treatment (HIT), and applied it to 37 participants from four Mental Health Centres in three Dutch provinces. All participants were involved in a ten-session education program. Thirty-nine participants formed the control group and received routine treatments.At follow-up time, five participants refused to participate and eight participants discontinued for personal reasons. As a result, 63 (31 in the experimental group and 32 in the control group) remained in the study. The results of this study showed that the reduction of the negative content of the voices and a reduced level of distress were higher in the experimental group compared to that of the control group. The authors predicted that HIT could also be applied to inpatient psychiatric patients, however further study about this prediction is needed.

A recent randomised control trial study by Penn, Meyer, Evans, Wirth, Cai and Burchinal (2009) compared the effectiveness of cognitive-behavioural therapy (CBT) and enhanced supportive therapy (EST) on the symptoms of schizophrenia. Sixtyfive participants were involved. Thirty-two participants were assigned to groups of four to seven in which they were exposed to CBT while 33 participants were assigned to similar sized groups and exposed to EST. The results of the study concluded that CBT is effective in reducing general psychotic symptoms while supportive therapy (EST) has a more specific effect in reducing negative beliefs toward auditory hallucinations.

An alternative treatment for managing auditory hallucinations, was suggested by Veiga-Martínez, Pérez-Álvarez, and GarciaMontes (2008). Using a single case study design, Veiga-Martínez, Pérez-Álvarez, and Garcia-Montes (2008) introduced Acceptance 
Suryani: A Critical Review of Symptom Management of Auditory Hallucinations

Commitment Therapy (ACT). Unlike CBT which proposes to reduce symptoms, ACT was applied to increase the acceptance of the illness. The study found that after being involved in 15 sessions of ACT, the participants' social network increased while the frequency of the voices decreased and the participants reported that they became less annoyed. However, during the period of attending the ACT sessions the participant continued his neuroleptic medication which may have influenced the findings of this study.

A most recent study conducted by Yang, Lee, Lo, and Beckstead (2015) in Taiwan examine the effectiveness of symptom management program that was developed by Bucchery (2007) in patients with chronic schizophrenia. Fifty-eight people experiencing schizophrenia with auditory hallucinations were divided into a control group and an experimental group. The experimental group received an auditory hallucinatory symptom management program which involved 60-minute meetings once a week, for a total of 10 meetings. The control group received routine care. Data were collected at baseline, immediately following the intervention and at 3 months and 6 months post intervention. The result showed that the experimental group achieved a greater drop in Characteristics of Auditory Hallucinations Questionnaire score than the controls at 3 and 6 months. This study concluded that symptom management programme effective in reducing the symptom of auditory hallucination.

\section{Conclusion}

An analysis of the findings of the studies discussed above shows that, despite some variations in study conclusions, there is strong evidence to suggest that $\mathrm{CBT}$ and other psychological treatments are of benefit for individuals who experience auditory hallucinations. In addition, it is important to note that individuals who experience auditory hallucinations are not just sufferers who need to be treated but people who can develop their own strategies of living with auditory hallucinations (Adame \& Knudson, 2007).

\section{Reference}

American Psychiatric Association. (2013). Diagnostic and Statistical Manual of Mental Disorders, (5th eds.). Washington, DC: American Psychiatric Association

Badcock, J.C. (2008). The Cognitive Neuropsychology of Auditory hallucinations: a parallel auditory hallucinations pathways framework. Schizophrenia Bulletin, 10, 1-9

Buccheri, R., Trygstad, L., \& Dowling, G. A. (2007). Behavioural management of command hallucinations to harm in schizophrenia. Journal of Psychosocial Nursing, 45(9), 46-54.

Buccheri, R., Trygstad, L., Kaas, M.J., Hopkin, R., Dowling, G., White, K., Griffin, Hebert, P. (2004). Long-term effect of teaching behaviour strategies for managing persistent auditory hallucinations. Journal of Psychosocial Nursing, 42(1), 19-26.

Cangas, A.J., Garcio-Mostes, J.M., Lopez de Lemus, M. \& Olivencia, J.J. (2003). Social and personality variables related to the origin of auditory hallucinations. International Journal of Psychology and Psychology Therapy, 3(2), 195-208.

Chadwick, P., Sambrooke, S., Raschc, S \& Davies, E. (2000). Challenging the omnipotence of voices: group cognitive behavior therapy for voices. Behaviour Research and Therapy, 38, 993-1003.

England, M. (2005). Mediation of the relationship between inner voice experiences and health related quality of live. Perspective in Psychiatric Care, 41(1), 22-36

England, M. (2007). Efficacy of cognitive nursing intervention for voice hearing. Perspective Psychiatric Care, 43(2), 69-76.

Hayashi, N., Igarashi, Y., Suda, K., \& Nakagawa, S. (2007). Auditory hallucination coping techniques and their relationship to psychotic symptomatology. Psychiatry and Clinical Neurosciences, 61, 640-645. 
Suryani: A Critical Review of Symptom Management of Auditory Hallucinations

Jenner, J.A., Nienhuis, F.J., Willige, G. \& Wiersma, D. (2006). "Hitting" voices of schizophrenia patients may lastingly reduce persistent auditory hallucinations and their Burden: 18 month outcome of randomized controlled trial. Canadian Journal of Psychiatry, 51(3), 169-177.

Jonston, O. Gallaghar, A.G., McMahon, P. \& King, D.J. (2002). The efficacy of using a personal stereo to treat auditory hallucinations: Preliminary findings. Behaviour Modification, 26(4), 537-549.

Kanungpairn, T, Sitthimongko, Y, Wattanapailin, A and Klainin, P (2007). Effects of a symptom management program on auditory hallucinations in Thai outpatients with a diagnosis of schizophrenia: A pilot study. Nursing and Health Sciences, 9, 34 39.

Lysaker, P., \& LaRocco, V. (2009). Healthrelated quality of life and trauma history in adults with schizophrenia spectrum disorders. The Journal of Nervous and Mental Disease, 197(5), 311-315.

Penn, D. L, Meyer, P. S., Evans, E., Wirth, R. J., Cai, K., \& Burchinal, M. (2009). A randomized controlled trial of group cognitive-behavioral therapy vs. enhanced supportive therapy for auditory hallucinations, Schizophrenia research, 109 (1-3): 52-59.

Singh, G., Sharan, p. \& Kulhara, P. (2002). Coping with Hallucinations in Schizophrenia: a Correlational Study. Hong Kong Journal of Psychiatry, 12(3), 5-11.

Suryani, Welch and Cox (2013). The Phenomena of Auditory Hallucination as Described by Indonesian People Living With Schizophrenia, Archive of Psychiatric Nursing, 27, 312-318.

Suryani (2013). Salat and Dhikr to Dispel
Voices: The Experience of Indonesian Muslim with Chronic Mental Illness. Malaysia journal of Psychiatry, 22(1).

Tsai, Y. \& Chen, C. (2005). Self-care symptom management strategies for auditory hallucinations among patients with schizophrenia in Taiwan. Applied Nursing Research, 19(4), 191-196.

Uhlhass, P. J., \& Mishara, A. L. (2006). Perceptual anomalies in schizophrenia: Integrating phenomenology and cognitive neuroscience. Schizophrenia Bulletin, 33(1), 142-156.

Veiga-Martínez, C. \& Pérez-Álvarez, M. \& Garcia-Montes, J. (2008). Acceptance and Commitment Therapy applied to treatment of auditory hallucinations. Clinical Case Studies, 7(2), 118-135.

Waters, F. (2010). Auditory hallucinations in psychiatric illness. Psychiatric Times, 27(3), 54-58.

Wykes, T. Hayward, P. \& Landau, S. (2000). Group treatment of auditory hallucination: Exploratory study of effectiveness. The British Journal of Psychiatry, 175(2), 180 185.

Wiersma, D., Jenner, J.A., van de Willige, G., Spakman, M. \& Nienhuis, F.J. (2001). Cognitive behaviour therapy with coping training for persistent auditory hallucinations in schizophrenia: a naturalistic followup study of the durability of effects. Acta Psychiatrica Scandinavia, 103, 393-399.

Yang, Lee, Lo, and Beckstead (2015). The effects of auditory hallucination symptom management programme for people with schizophrenia: a quasi-experimental design. Journal of Advance Nursing, 71(12): 28862897. 